\title{
Mansonelliasis, a neglected parasitic disease in Haiti
}

\author{
Christian Pierre Raccurt ${ }^{1 /+}$, Philippe Brasseur ${ }^{2}$, Jacques Boncy ${ }^{1}$ \\ ${ }^{1}$ Laboratoire National de Santé Publique, Port-au-Prince, Haïti ${ }^{2}$ Unité de Recherche sur les Maladie Infectieuses Tropicales Emergentes, \\ Unité Mixte de Recherche 198, Institut de Recherche pour le Développement, Dakar, Sénégal
}

Reported in Haiti as early as 1923, Mansonella ozzardi is still a neglected disease ignored by the health authorities of the country. This review is an update on the geographic distribution of the coastal foci of mansonelliasis in Haiti, the epidemiological profile and prevalence rates of microfilariae in people living in endemic areas, the clinical impact of the parasite on health and the efficiency of the transmission of the parasite among three Culicoides biting-midge species identified as vectors in Haiti. Additionally, interest in establishing a treatment programme to combat this parasite using a single dose of ivermectin is emphasised.

Key words: mansonelliasis - Mansonella ozzardi - Haiti - neglected tropical disease

Mansonella ozzardi was first reported in Haiti by the Rockefeller mission in 1924 (Raccurt 1999) and remained unknown among medical authorities for 50 years. In 1974, a thick-smear study performed throughout the country by the National Service of Major Endemic Diseases (SNEM) showed the presence of microfilariae in peripheral blood, which were identified as $M$. ozzardi in most cases (Ripert et al. 1977). Following this rediscovery, epidemiological and entomological studies were conducted in Haiti (Raccurt et al. 1980, 2014, Lowrie Jr \& Raccurt 1981, 1984, Lowrie Jr et al. 1983). To date, health authorities have paid no attention to this disease and, as a result, mansonelliasis can be considered as a neglected filariasis. This review reviews knowledge about M. ozzardi and its vectors in Haiti. The slight pathogenicity of this parasite is most likely related to the little interest in this filariasis among health authorities.

A mapping of foci of mansonelliasis in Haiti has been established using the geographic origin of $M$. ozzardi microfilaria carriers detected by the SNEM study (Ripert et al. 1977). The data showed that all of the foci are strictly located in the coastal areas. A large focus is located in the north, between Port-de-Paix and Cap Haitien. Another large focus is located in the Miragoâne area, within the Nippes district. This focus includes the area stretching from Petit-Trou-de-Nippes to Roseaux in the Grande Anse district, including the Baradères peninsula and the Cayemites islands. In the south, a focus is located in the Saint-Louis-du-Sud area, near Les Cayes and on the island Ile à Vache. Limited foci are located in the western district, north of Port-au-Prince, in Leogane and around Gonâve Island.

doi: 10.1590/0074-0276140107

+ Corresponding author: raccurt@yahoo.fr

Received 26 March 2014

Accepted 1 July 2014
In Haiti, M. ozzardi microfilariae have rarely been detected in infants. Among the 489 cases reported in 1974, only two paediatric cases were identified, affecting a six-month-old and an eight-month-old. In contrast, $91 \%$ of carriers were found to be adults more than 20 years old (Ripert et al. 1977). An epidemiological study, performed in collaboration with the Department of Tropical Medicine of Tulane University (Raccurt et al. 1980) and conducted on 1,165 inhabitants of Bayeux, in the north, from 1977-1979, showed a $16.1 \%$ prevalence of microfilariae in $20 \mu \mathrm{L}$ of peripheral blood. Among those tested, only $1.4 \%$ of positive cases affected two19 -year-olds. In adults, males were infected twice as often as females were (48.8\% vs. $23.5 \%$, respectively) and prevalence increased with age. In 1983, a prevalence of $18.8 \%$ was reported among 80 inhabitants of Bon Dos, a small fishing village in the Nippes district (Raccurt 1984). An open study conducted in 2013 in Corail, located in Grande Anse district, showed a $16.5 \%$ prevalence among inhabitants and positivity was less than $2 \%$ in those under 15 years old (Raccurt et al. 2014). In contrast to the study in Bayeux, performed 35 years before, 23\% of positive adults were male and $21 \%$ were female. The density of blood microfilariae was weak in Haiti. In Bayeux, 134/188 (71\%) of positive individuals had one-nine M. ozzardi microfilariae in $20 \mu \mathrm{L}$ of peripheral blood and in $27 \%$, only one microfilaria was found. In Corail, $70 \%$ of the 76 carriers had less than 10 microfilariae per $20 \mu \mathrm{L}$ and only $5 \%$ had 50 or more. Rare cases with high levels of microfilariae were observed in three males (109, 149 and 560 microfilariae per $20 \mu \mathrm{L})$.

M. ozzardi is considered to be a non or only slightly pathogenic filaria. An evaluation of morbidity among 150 inhabitants of Bayeux in 1984 confirmed that there was no major disorder due to the presence of this parasite (McNeeley et al. 1989). However, a high level of eosinophilia was strongly related to parasitic density. Few non-specific clinical signs were frequently reported by patients, such as pruritus, headache, joint pain and fever. Recently, in Brazil, among Indian and riverine communities living in mansonelliasis foci (Garrido \& Campos 2000, Cohen et al. 2008, Vianna et al. 2012), $M$. 
ozzardi microfilariae were considered to be a cause of ocular lesions and particularly nummular keratitis. Consequently, a systematic examination for ocular lesions is appropriate among microfilaria carriers.

In Haiti, the main vector is Culicoides furens, which was identified at brackish or freshwater breeding sites during the studies in Bayeux, in the north, from 19771980. Within the vector, the microfilariae required nine days to reach the infective stage (Lowrie Jr \& Raccurt 1981). The infestation rate of $C$. furens is correlated to the microfilaria density of the carrier from whom it is taking blood. In 1983, studies in Bon Dos, located in the Nippes district in the southern peninsula of Haiti, showed that the biting midge Culicoides barbosai was capable of supporting the development of $M$. ozzardi to the infective stage, with a capacity to transmit $M$. ozzardi as potent as that of C. furens (Lowrie Jr \& Raccurt 1984). This species breeds exclusively in mangrove salt marshes (Raccurt 1984).

A third species of Ceratopogonidae, Leptoconops bequaerti, which breeds in sand on beaches, can ensure $M$. ozzardi maturation to third-stage larvae, but with a more limited efficiency than that of $C$. furens and C. barbosai (Lowrie Jr et al. 1983).

M. ozzardi persists in Haiti, as in several countries of South America, where it occurs in small foci with a high prevalence rate, especially infecting adults. In contrast to the Amazon Basin and northern Argentina, where Simuliid blackflies are the main vectors of $M$. ozzardi (Shelley \& Shelley 1976, Shelley et al. 1980, Tidwell et al. 1980, Nathan et al. 1982, Tidwell \& Tidwell 1982, Shelley \& Coscarón 2001), only Culicoides are responsible for transmission in the Caribbean. In Haiti, six main coastal foci have been identified in the mangrove areas where fishermen live and C. furens and C. barbosai breed and in the swampy plains along the coast, where farmers live, which are favourable to $C$. furens proliferation. The high prevalence rates observed in Haiti are close to those reported in the Amazonian area (Lightner et al. 1980, Kozek et al. 1982, 1983, 1984, Formica \& Botto 1990, Bartoloni et al. 1999, Gómez \& Guerrero 2000, Medeiros et al. 2008, 2009, 2011, 2014, Martins et al. 2010, Basano et al. 2011, Adami et al. 2014) and in the northeast of Argentina (Taranto \& Castelli 1988). The non-specific symptoms reported in most cases could not be easily related to M. ozzardi. However, since 2000, ocular lesions have been reported in Brazil (Garrido \& Campos 2000, Cohen et al. 2008, Vianna et al. 2012), requiring management of these patients. Whereas usual antifilarial drugs are not effective for treating M. ozzardi infection, the use of ivermectin has proven to be very effective against microfilariae (Nutman et al. 1987). A decrease of $82.5 \%$ in microfilaria density was obtained in Trinidad four years after treatment with a single dose of $6 \mathrm{mg}$ ivermectin among adult carriers (Gonzales et al. 1999). In Brazil, significant microfilaraemia reduction was observed and its residual effect was maintained for at least 12 months (Basano et al. 2014). However, certain early side effects, such as Mazzotti reactions, have been reported in Argentina (Krolewiecki et al. 2011). Considering the importance of the foci in Haiti and the high prevalence of infection in adults first and the possibility of mansonelliasis dissemination to other non-endemic regions due to the large migration of Haitians second, ivermectin treatment could be recommended for carriers identified during a control programme for this neglected parasite. Special care should be taken for those with high parasitaemia to prevent and to cure early side effects, such as Mazzotti reactions, because the intensity and severity of the side effects seem to be correlated with the parasitic load before treatment. With the migration of Haitians to the Caribbean and South America, where vectors of $M$. ozzardi are present, filariasis expansion is of concern, particularly in the Amazonian countries.

\section{REFERENCES}

Adami YL, Rodrigues G, Alves MC, Moraes MAP, Banic DM, MaiaHerzog M 2014. New records of Mansonella ozzardi: a parasite that is spreading from the state of Amazonas to previously uninfected areas of the state of Acre in the Purus River region. Mem Inst Oswaldo Cruz 109: 87-92.

Bartoloni A, Cancrini G, Bartalesi F, Marcolin D, Roselli M, Arce CC, Hall AJ 1999. Mansonella ozzardi infection in Bolivia: prevalence and clinical associations in the Chaco region. Am J Trop Med Hyg 61: 830-833.

Basano SA, Camargo JS, Vera LJ, Velasques SN, Ogawa GM, Medeiros JF, Fontes G, Camargo LM 2011. Investigation of the occurrence of Mansonella ozzardi in the state of Rondônia, western Amazonia, Brazil. Rev Soc Bras Med Trop 44: 600-603.

Basano SD, Fontes G, Medeiros JF, Camargo JS, Vera LJ, Araújo MP, Parente MS, Ferreira RD, Crispim PD, Camargo LM 2014. Sustained clearance of Mansonella ozzardi infection after treatment with ivermectin in the Brazilian Amazon. Am J Trop Med Hyg 90: $1170-1175$.

Cohen JM, Ribeiro JA, Martins M 2008. Ocular manifestations in mansonelliasis. Arq Bras Oftalmol 71: 167-171.

Formica S, Botto C 1990. Filariasis focus due to Mansonella ozzardi and Mansonella perstans in the Amazon federal territory of Venezuela. J Trop Med Hyg 93: 160-165.

Garrido C, Campos M 2000. First report of presumed parasitic keratitis in Indians from the Brazilian Amazon. Cornea 19: 817-819.

Gómez J, Guerrero R 2000. Environmental factors and the distribution of mansonelliases in southern Venezuela. Parasite 7: 71-76.

Gonzalez AA, Chadee DD, Rawlins SC 1999. Ivermectin treatment of mansonellosis in Trinidad. West Indian Med J 48: 231-234.

Kozek WJ, D’Alessandro A, Silva J, Navarette SN 1982. Filariasis in Colombia: prevalence of mansonellosis in the teenage and adult population of the Colombian Bank of the Amazon. Am J Trop Med Hyg 31: 1131-1136.

Kozek WJ, Palma G, Henao A, García H, Hoyos M 1983. Filariasis in Colombia: prevalence and distribution of Mansonella ozzardi and Mansonella (= Dipetalonema) perstans infections in the Comisaría del Guainía. Am J Trop Med Hyg 32: 379-384.

Kozek WJ, Palma G, Valencia W, Montalvo C, Spain J 1984. Filariasis in Colombia: prevalence of Mansonella ozzardi in the Departamento del Meta, Intendencia del Casanare and Comisaría del Vichada. Am J Trop Med Hyg 33: 70-72.

Krolewiecki AJ, Cajal SP, Villalpando C, Gil JF 2011. Ivermectinrelated adverse clinical events in patients treated for Mansonella ozzardi infections. Rev Argent Microbiol 43: 48-50.

Lightner LK, Ewert A, Corredor A, Sabogal E 1980. A parasitologic survey for Mansonella ozzardi in the Comisaría del Vaupés, Colombia. Am J Trop Med Hyg 29: 42-45. 
Lowrie Jr RC, Raccurt C 1981. Mansonella ozzardi in Haiti. 2. Arthropod study. Am J Trop Med Hyg 30: 598-603.

Lowrie Jr RC, Raccurt CP 1984. Assessment of Culicoides barbosai as a vector of Mansonella ozzardi in Haiti. Am J Trop Med Hyg 33: $1275-1277$.

Lowrie Jr RC, Raccurt CP, Eberhard ML, Katz SP 1983. Assessment of Leptoconops bequaerti as a potential vector of Mansonella ozzardi in Haiti. Am J Trop Med Hyg 32: 1013-1015.

Martins M, Pessoa FAC, de Medeiros MB, de Andrade EV, Medeiros JF 2010. Mansonella ozzardi in Amazonas, Brazil: prevalence and distribution in the municipality of Coari, in the middle Solimões River. Mem Inst Oswaldo Cruz 105: 246-253.

McNeeley DF, Raccurt CP, Boncy J, Lowrie Jr RC 1989. Clinical evaluation of Mansonella ozzardi in Haiti. Trop Med Parasitol 40: $107-110$.

Medeiros JF, Costa CA, Lima AM, Pessoa FA 2014. Mansonella ozzardi (Nematoda: Onchocercidae) in the riverine population of the Tefé River, state of Amazonia, Brazil. Rev Soc Bras Med Trop 47: 113-115.

Medeiros JF, Py-Daniel V, Barbosa UC 2011. Prevalence of Mansonella ozzardi among riverine communities in the municipality of Lábrea, state of Amazonas, Brazil. Rev Soc Bras Med Trop 44: 186-190.

Medeiros JF, Py-Daniel V, Barbosa UC, Izzo TJ 2009. Mansonella ozzardi in Brazil: prevalence of infection in riverine communities in the Purus region, in the state of Amazonas. Mem Inst Oswaldo Cruz 104: 74-80.

Medeiros JF, Py-Daniel V, Barbosa UC, Ogawa GM 2008. Current profile of Mansonella ozzardi (Nematoda: Onchocercidae) in communities along the Ituxi River, Lábrea municipality, Amazonas, Brazil. Mem Inst Oswaldo Cruz 103: 409-411.

Nathan MB, Tikasingh ES, Munroe P 1982. Filariasis in Amerindians of western Guyana with observations on transmission of Mansonella ozzardi by a Simulium species of the amazonicum group. Tropenmed Parasitol 33: 219-222.

Nutman TB, Nash TE, Ottesen EA 1987. Ivermectin in the successful treatment of a patient with Mansonella ozzardi infection. J Infect Dis 156: 662-665.
Raccurt C, Lowrie Jr RC, McNeeley DF 1980. Mansonella ozzardi in Haiti. 1. Epidemiological survey. Am J Trop Med Hyg 29: 803-808.

Raccurt CP 1984. Contribution à l'étude de Mansonella ozzardi (Nematoda, Onchocercidae) et de ses vecteurs (Diptera, Ceratopogonidae) en Haïti, PhD Thesis, Université Claude Bernard Lyon 1, Lyon, 176 pp.

Raccurt CP 1999. Filarioses en Haïti, un siècle d'histoire. Bull Soc Pathol Exot Filiales 92: 355-359.

Raccurt CP, Brasseur P, Ciceron M, Boncy J 2014. Epidemiological survey of Mansonella ozzardi in Corail, Haiti. Am J Trop Med Hyg 90: 1167-1169.

Ripert C, Raccurt C, Douyon PL 1977. La filariose Mansonella ozzardi en Haïti (Grandes Antilles). Premières données épidémiologiques. Bord Med 10: 689-696.

Shelley AJ, Coscarón S 2001. Simuliid blackflies (Diptera: Simuliidae) and ceratopogonid midges (Diptera: Ceratopogonidae) as vectors of Mansonella ozzardi (Nematoda: Onchocercidae) in northern Argentina. Mem Inst Oswaldo Cruz 96: 451-458.

Shelley AJ, Dias APL, Moraes MA 1980. Simulium species of the amazonicum group as vectors of Mansonella ozzardi in the Brazilian Amazon. Trans R Soc Trop Med Hyg 74: 784-788.

Shelley AJ, Shelley A 1976. Further evidence for the transmission of Mansonella ozzardi by Simulium amazonicum in Brazil. Ann Trop Med Parasitol 70: 213-217.

Taranto NJ, Castelli E 1988. Detección de un foco de filariasis en el noroeste argentino. Rev Argent Microbiol 20: 49-51.

Tidwell MA, Tidwell MA 1982. Development of Mansonella ozzardi in Simulium amazonicum, S. argentiscutum and Culicoides insinuatus from Amazonas, Colombia. Am J Trop Med Hyg 31: 1137-1141.

Tidwell MA, Tidwell MA, de Hoyos PM 1980. Development of Mansonella ozzardi in a black fly species of the Simulium sanguineum group from eastern Vaupés, Colombia. Am J Trop Med Hyg 29: $1209-1214$

Vianna LMM, Martins M, Cohen MJ, Cohen JM, Belfort Jr R 2012. Mansonella ozzardi corneal lesions in the Amazon: a cross-sectional study. BMJ Open 2: e001266. 